\title{
Correction: Impella versus IABP in acute myocardial infarction complicated by cardiogenic shock
}

Alushi B, Douedari A, Froehlig G, et al. Impella versus IABP in acute myocardial infarction complicated by cardiogenic shock. Open Heart 2019;6:e000987. doi:10.1136/ openhrt-2018-000987

The authors want to alert readers to the following error identified in the published version.

The co-author name Barbara-Elisabeth Staehli has incorrectly published the correct name of the author is Barbara Elisabeth Stahli

Open access This is an open access article distributed in accordance with the Creative Commons Attribution Non Commercial (CC BY-NC 4.0) license, which permits others to distribute, remix, adapt, build upon this work non-commercially, and license their derivative works on different terms, provided the original work is properly cited, appropriate credit is given, any changes made indicated, and the use is non-commercial. See: http://creativecommons.org/licenses/by-nc/4.0/.

(C) Author(s) (or their employer(s)) 2019. Re-use permitted under CC BY-NC. No commercial re-use. See rights and permissions. Published by BMJ.

Open Heart 2019;6:e000987corr1. doi:10.1136/openhrt-2018-000987corr1

Check for updates 